\title{
AFFECT AND AUTHORITY IN IMMIGRATION DETENTION ${ }^{1}$
}

'At the end of the day our job is to tell the detainees what they can have and what they can't have.' (Donald, ${ }^{2}$ DCO, IRC Harmondsworth)

'law without appeals to emotion is virtually unthinkable.' (Nussbaum, 2004: 6)

In this paper, I draw on a selection of staff accounts of working in British Immigration Removal Centres (IRCs), to explore how power and authority are maintained and challenged within these sites. As I will demonstrate, officers speak about their work in contradictory and, often, in deeply emotional ways. IRCs are not 'happy places to work', they say; they feel 'worthless', and have to become 'hardened' to survive. The point is not to generate sympathy for these women and men; they are not heroic figures. ${ }^{3}$ Rather, in focusing upon the emotional quality of their testimonies, I highlight the importance of affect in making sense of the social world (Clough and Halley, 2007; Mercan, 2018; Chamberlen, 2016). In so doing, I seek to open new lines of thought within criminological accounts of power and legitimacy. For emotions, Sara Ahmed (2004a; 2004b) reminds us, are productive. They are a means by which people make sense of themselves and the world around us (see also Nussbaum, 2001; 2004; Katz, 1999). They indicate a moral and ethical frame (Sedgwick, 2003), while also acting as a form of and as a vehicle for control. Emotions can be a site of critical resistance and a coming together, as well as means of division. They create ties and may sever them.

Notwithstanding a lengthy tradition within criminology of work on emotions, crime (Katz, 1988), and punishment (Karstedt et al, 2011; Braithwaite, 1989), rather less attention has been paid to the affective nature of the administration of justice as criminologists have emphasized the 'rational' side of bureaucratic practice over its emotional one (Weber, 1997; although see Murphy \& Tyler, 2008). Thus, even as sociologists have long documented the pain prisoners feel as a result of their confinement (see, for example, Sykes, 1958; Cohen and Taylor, 1972; Crewe, 2009), and some attention has been given to the emotional impact of working in prisons (although see Crawley, 2004a; 2004b; 2011), little has been written on institutional affect (although see Chamberlen, 2016). Rather, since the mid-1990s, authority and coercion have been predominantly conceptualized in liberal terms of power and legitimacy (see, inter alia, Sparks, 1994; Sparks, Bottoms and Hay, 1996; Liebling and Tankebe, 2015; Bradford et al, 2013; Bradford and Quinton, 2014; Dolovich, 2004).

\footnotetext{
${ }^{1}$ With thanks to the editors and anonymous reviewers at the journal, and to Lucia Zedner, Dominic Aitken, Alison Liebling, Emma Kaufman, Ben Crewe and members of the 2017

Cambridge Prisons MSt programme all of whom gave me useful feedback on earlier versions of this paper.

2 Not his real name, all participants have been allocated pseudonyms.

${ }^{3}$ Recent events, particularly in the 2018 separation of asylum-seeking families at the US border, but also closer to home in the UK, evident in the 2017 BBC exposé of officer brutality in IRC Brook House, remind us that those who work in sites of detention and border control are capable of considerable brutality.
} 
While important distinctions exist within the broad field of scholarship on legitimacy (see, for a good overview, Liebling and Tankebe, 2015), for the most part authors attribute a certain level of contingency to power and authority. Even in sites of apparent coercion, they argue, power is negotiated (although see Carrabine, 1999). The state does not operate without limits. Instead, the power wielded by individuals and organisations relies on 'the recognition by the governed of that right' to govern (Bradford, et al, 2013: 80). In the words of Tony Bottoms and Justice Tankebe (2012: 129):

'Legitimacy needs to be perceived as always dialogic and relational in character. That is to say, those in power (or seeking power) in a given context make a claim to be the legitimate ruler(s); then members of the audience respond to this claim; the power-holder might adjust the nature of the claim in light of the audience's response; and this process repeats itself. It follows that legitimacy should not be viewed as a single transaction; it is more like a perpetual discussion, in which the content of power-holders' later claims will be affected by the nature of the audience response.'

As I will make clear below, such an approach, which assumes a liberal political frame, rather than an authoritarian one (Haney, 2016) or some other arrangement altogether (Aas and Bosworth, 2013), has limited explanatory value for IRCs. ${ }^{4}$ It does not help us understand how authority is wielded or contested, nor how power flows, because there cannot be mutual recognition in these institutions which are premised on and facilitate exclusion. Awaiting deportation, already cast out from among us, immigration detainees are symbolically and practically denied membership of any meaningful 'audience' who would negotiate with 'power-holders'. Thus, they often describe their incarceration in illiberal terms as slavery or kidnapping. Their loss of liberty, they say, is a consequence for the crime of simply being who they are: foreign (Bosworth, 2013; 2014).

For the purpose of this paper, I concentrate on how officers conceive of their role and the power they wield in these sites. As I will demonstrate, their testimonies, suggest a fundamental confusion over the purpose and nature of these institutions and their place in it. Officers report difficulty in forging relationships with those in their care. Communicating across language barriers and cultural differences can be taxing. Detainees are unpredictable, angry and distressed. Nobody knows how long they will be detained, and officers rarely learn what happens to those who leave. Institutionally they are exhorted to maintain distance from detainees, while having to work with them intimately, sometimes for months or even years at a time. As a result, they tend to rely on racialized and gendered stereotypes, which, particularly in these securitized environments, make bonds harder to form (Bosworth, 2018). Officers feel economically

\footnotetext{
${ }^{4}$ For abolitionists, the liberal promise of prisons is also false and, is indeed, often fed by criminological work itself that seeks to reform and improve the system (see, for example, Brown and Schept, 2017).
} 
precarious and stigmatized. Their agency is limited by their relationship to the Home Office.

Many respond to these complex and contradictory circumstances cynically. They feel bitter and frustrated, openly blame or disbelieve detainees. Like employees everywhere, they are critical of management and, particularly with their long shifts, find it hard to develop a healthy relationship between home and work. Although there are always some exceptions, -- everyone everywhere has an account in which they connected with a detainee -- for the most part, staff turn away (emotionally withdraw) from those in their care, and also from themselves. Their 'authentic' self exists outside the gate, they insist, and they try, usually in vain, to maintain a split sense of being.

In these terms, and in contrast to much criminological literature on the prison, that advances a liberal political account in which power is constantly negotiated and based on mutual recognition, staff testimonies from detention paint a far darker reality. Authority, their narratives suggest, rests on an abrogation of their self rather than on engagement with the other (Levinas, 1969; Arendt, 2003). Not only are IRCs outside the liberal political frame, into which, by definition, foreigners never quite fit (Honig, 2001), their words imply, but also, more insidiously, these institutions corrode moral responsibility. Operating without legitimacy may work, in other words, but only at considerable cost.

\section{Immigration Detention and Research: The Context}

The immigration detention system in the UK is run on behalf of the Home Office on a contracted-out model by a series of private custodial companies and the prison service (HMPPS). On any one day, it holds around 2600 women and men, plus a handful of children, awaiting deportation or administrative removal. Most are citizens from former British colonies, or from current or recent war zones. There are also a growing number of people from Eastern Europe (Home Office, 2018). At the time of writing there are five different providers managing eight establishments - HMPPS (IRC Morton Hall), GEO (IRC Dungavel), G4S (IRC Tinsley House and IRC Brook House), Mitie (IRC Campsfield House, IRC Harmondsworth and IRC Colnbrook) and Serco (IRC Yarl's Wood). ${ }^{5}$

In contrast to the amount of published information available about detainees, the government and the private custodial firms produce very little official information about staff. They rarely feature in the 'grey literature' on detention, produced by NGOs and government agencies ${ }^{6}$ other than appearing

\footnotetext{
${ }^{5}$ Despite numerous attempts by a range of activists and lawyers to discover the terms of the contracts, the legal documents remain unavailable for independent scrutiny. Instead, all we know for sure is that the centres must follow the Immigration Detention Centre Rules 2001, the Home Office Operating Standards, and a selection of detention service orders (DSOs). Further explanation about the purpose and nature of immigration removal centres are also listed in Chapter 55 of Home Office Enforcement Instructions and Guidance. Finally, these sites are governed by a certain amount of case law, and, more broadly, by the Human Rights Act, 1998 .

${ }^{6}$ For the first time in 2018, HM Inspectorate of Prisons who monitor sites of detention included a staff survey and some interviews in their methodology. See, for example, HMIP, 2018. Also in
} 
briefly in some of the reports by the Independent Monitoring Board (see for example, IMB 2014), and few academics pay them much attention (although see Hall, 2012; Bosworth 2014; 2016). Such oversight is not unique to the detention estate. Relative to the volume of work published about prisoners, for example, we know far less about prison officers, although matters are slowly changing (see, for example, Liebling, 2011; Crew et al, 2011; Wooldredge and Steiner, 2016; Lerman and Page, 2012). Similarly, accounts of hospitals and schools tend to focus on patients and children, in preference to doctors, nurses or teachers. In this section I draw on my own research, that I have been conducting in IRCs since 2009.

From this work, a few themes emerge. Like detainees, most officers across all centres are male. ${ }^{7}$ Most also are white, although two of the sites which appear in this paper, IRC Harmondsworth and IRC Colnbrook, which together make up Heathrow IRC, employ a higher proportion of black and ethnic minority staff than elsewhere. ${ }^{8}$ Even here, however, diversity declines in the higher echelons of staff (Bosworth, 2018). Officers come to work in detention from a range of different backgrounds, and it is impossible to list or enumerate them all. Common histories include previous experience in the armed forces, retail, homemaking, and other security work (eg as bouncers or at the airport). Some staff have come straight from school.

Detention work is organized into a steep hierarchy, from Auxiliary Detainee Officers (AO) to the non-uniformed Senior Management team (SMT) headed by the Centre Manager. The most common grade is a detainee custody officer (DCO), who constitute the majority of workers. They are overseen by Detainee Custody Managers (DCMs) who tend to specialize in specific aspects of the regime and who are, in turn, monitored by a member of the SMT. Recent job advertisements reveal a fairly generous starting salary for DCOs in the mid- $£ 20,000$ s, with no educational requirements beyond a GCSE. For this salary, they work long shifts, with limited job security and few opportunities for career advancement.

Officers receive 6 weeks of training, much of which is learned on the job. Compulsory elements of preparation to work in detention include 'control and restraint' (C\&R), diversity, interpersonal skills, an overview of the Human Rights Act and the ECHR and first aid as set out in the Detention Services Order 02/2018. At the institutional level, officers describe a high turnover of recruits. Like detainees, custodial employees stay in post for varying and unpredictable periods of time. Some last for years, others give up almost immediately.

2018, the follow-up to the Shaw Review into the welfare of vulnerable people in detention examined staff culture (Shaw, 2018). My research has contributed to both of these developments.

7 There are some exceptions. For instance, as the primary site for female detainees, IRC Yarl's Wood has many female staff.

${ }^{8}$ In a 2015 survey on staff culture in these two institutions, for example, from a sample of 88 respondents, just over $26 \%$ of respondents self-identified as BME (Bosworth, Gerlach and Aitken, 2016). 
As noted above, I have been conducting research inside IRCs since $2009^{9}$, during which I have amassed a significant amount of material about staff and detainee experiences. Most of the testimonies in this article come from semi-structured interviews and informal conversations with 89 staff members at IRC Harmondsworth and IRC Colnbrook which were gathered over a four-month period, from September 2015 - December 2015 as part of a mixed-method study of 'staff culture' (Bosworth, Gerlach and Aitken, 2016; Bosworth, 2018). Research participants included all officer grades from AOs to members of the SMT. Just over one-third of the sample (37\%) were women, and of those whose ethnic identity was recorded (82 out of the total 89), 33\% self-identified as Asian, Black or mixed-race.

For the purpose of illustration and to widen the applicability of the study, this material is supplemented by more recent work in IRC Morton Hall, which was conducted the following year, as well as with some earlier interviews from officers in IRC Yarl's Wood and IRC Campsfield House. ${ }^{10}$ In all sites, the qualitative component of the research included informal observation and conversation with semi-structured interviews. Certain participants acted as gatekeepers, allowing me to generate a snowball sample, as they recommended others whom they thought would be interested. While I did not attempt a random sample, I did make efforts to invite a range of staff according to BME status, gender, seniority and experience.

I was particularly interested in staff views on legitimacy, authority, fairness, and discretion as they pertained to their experience of working in an IRC. In order to access these concepts, I asked officers questions about their views on the purpose of detention, the relationship of detention to imprisonment, the experiences of BME and female officers, on the Home Office and the custodial company for whom they worked. I also sought, rather more prosaically, to understand what officers do each day and how they interacted with detainees.

Interviews in all centres were conducted in private, and nearly all were recorded. Two of the interviews were written down in note form instead. Those meetings that were recorded were later transcribed verbatim. All transcripts, plus fieldnotes were manually coded according to a series of themes including: race/ethnicity; gender; employment; legitimacy; privatization; family; staffing; procedural fairness, decency, discretion; relationships; safety; public opinion; prison; management; mental health; engagement; trust and authority. The quotes have been selected from close reading and transcripts and field notes to reflect commonly held views, yet, I make no claim to their universality or generalizability. Instead, I read them for the ideas they inspire, rather than the facts they assert.

\footnotetext{
${ }^{9}$ Throughout this period of time, I have been the sole academic permitted to enter IRCs freely, access that I have been able to extend to colleagues and students working with me (For further details see Bosworth and Kellezi 2017). As a result, and notwithstanding a vigorous body of academic work on immigration detention, daily life within these sites remains under-studied. 10 I was assisted by Dominic Aitken in IRC Heathrow and by Blerina Kellezi in IRC Yarl's Wood and IRC Morton Hall. They conducted some of the interviews.
} 


\section{Working in Detention: Affect, Authority and the Self}

Staff are both precarious and powerful. Their jobs are routinized and varied. Officers wield considerable discretion within the centres, yet have very little influence over the matter that brings people to them, namely their immigration case. Many find it difficult to articulate the purpose and impact of their work. As a result, and in some contrast to the literature on legitimacy which directs our attention to the nature of life inside custodial establishments (Crewe, 2009; Sparks, 1994; Liebling, 2004), for an understanding of their purpose, IRCs remain opaque on both counts (Bosworth, 2013). In describing some of the work by DCOs, and their accounts of that labour, I seek to illuminate both the incoherence of these institutions and the implications of how staff try to make sense of them. As I will show, officers not only find it difficult to build meaningful relationships with detainees, but also with themselves. This rupture, with the other and with their self, can be profoundly painful and destabilizing, yet it does not stop them from doing their job.

Most often, DCOs compare their role to that of a prison officer. "I just say it's like a prison officer" Lola noted, when she was asked how she explained her job to her family and friends (DCO, IRC Harmondsworth). Yet, by no means is this view uncontested, nor is it always coherent. Astrid, who had worked at IRC Harmondsworth for over ten years, first characterized her job in similar terms to Lola. "I'm a detention custody officer, which is like a prison officer, in an immigration removal centre,' she stated, before referring to her work in quite different terms, and then circling back to the comparison with the prison. "I babysit," she said, "I look after people who are going to be deported or released. That's literally what I say [to anyone who asks about my job]. I'm basically a prison officer, but the first word's different; that's all." (DCO, IRC Harmondsworth).

Some, like Paul, were anxious to distinguish themselves from penal colleagues. His job in an IRC was far more interesting he assured me. The distinction between the two careers, he suggested, sprang from the uncertain duration of detention:

'I think, as a prison officer, every day would be exactly the same. You go in, you unlock, you do this, you do that. Those guys are in there for three months, for eight months, fifteen. These guys don't have a clue. They have no idea whether they're gonna wake up in the morning and be released, or whether they're gonna get that ticket for a flight. I think all of that, all mixed in, just makes it really... interesting' (DCM, IRC Colnbrook)

Others, like Joyce, offered more muted definitions still, comparing IRCs to a "boarding school" (DCM, IRC Colnbrook), or defining their role as a caring, rather than a custodial one. "I'm here to look after their welfare, just like doctors are there to save people's lives, in a different way" Garima claimed (DCO, IRC Harmondsworth). Still others search unsuccessfully for a comparison, with Luke offering a particularly obscure opinion that he saw himself professionally, as "somewhere between a milkman and a police officer" (DCM, IRC Harmondsworth). 
In affective terms, such contradictory accounts of the DCO role can be considered forms of denial. Paul's pleasure in his work that he found so 'interesting', for instance, was only possible if he overlooked the distress of those in his care, and the extensive evidence of the negative impact of uncertainty on detainees (Bosworth, 2016). So, too, Joyce and Garima's claims that IRCs are 'like' school or DCOs akin to the medical profession are only tenable if their role in expulsion is disregarded.

More prosaically, some of the officers' confusion springs from the varied, albeit humdrum nature of their daily work. Within an IRC, DCOs are usually set specific tasks within a particular aspect of the detention regime. While they can be, and usually are, moved around during their shift and certainly over time, officers tend to specialize in certain areas. Some work in activities, others on the housing units, in security, in visits, in reception, healthcare, the 'legal corridor', or in welfare. Wherever they are primarily based, much of their day-to-day labour is banal and repetitive. They hand out tweezers, razors, sanitary pads; fax lawyers and the Home Office; change bed sheets as women and men are removed, released, deported or moved to another establishment; tick names off the lunch list; patrol the perimeter; conduct 'fabric checks' to ensure items in the rooms are in reasonable condition. At the same time, they perform all these tasks with a highly anxious and distressed population, most of whom have limited English language skills and complex needs. Officers also monitor the risk of suicide and self-harm; assist in locating family members abroad; try to navigate the British care system; help detainees find lawyers; liaise with onsite immigration officers; welcome new arrivals and hand over others to those who will force them onto a plane.

Structural, institutional arrangements further muddy the waters. Like other contracted out systems, IRCs rely on and generate a certain precarity among their workforce. HMPPS and the private companies increasingly seek to operate IRCs with fewer staff or with less experienced personnel, in a bid to cut costs. In Yarl's Wood, for instance, Serco pioneered what they refer to as a 'hotel model', which operates with minimal officers and a growing reliance on technology to deliver basic services. In this system, which other centres are adopting too, officers are encouraged to think of themselves as 'concierges', signposting detainees to information and services. Such strategies may be based in a laudable attempt to operate these sites in deliberately non-penal ways, despite their architecture and policy frame. Yet, in their language of tourism and leisure they deny the purpose and nature of these places. Such a view of this job, Hasan noted, overlooked one key issue: that IRCs are, inherently coercive, and that his role, as a DCO, is, at its most basic point, to maintain order and control. 'You can be a concierge', he said, 'right up to the point you can't. Obviously, we have to use force if we must. But we try not to.' (Hasan, DCM, IRC Harmondsworth). Detainees are neither willing guests nor holiday-makers; in the terminology of the private sector, the Home Office is the 'customer', and the service they have purchased from the custodial providers is custody. 'It's not a hotel is it?' Gopal noted impatiently, when reporting how the men demanded options he could not or did not wish to accommodate. 'Can't share with this guy, don't like this room', he muttered scornfully. (DCO, IRC Colnbrook). 
It is not just symbolically where the 'hotel model' falls short, but also in the practical impact of its reduced staff numbers. In their 2014 annual report on IRC Heathrow, for instance, the Independent Monitoring Board (IMB) commented anxiously:

'Staffing levels do not seem adequate to meet the needs of detainees. Staff morale is low. This adversely affects the welfare of detainees. The IMB continued to receive complaints about staff behaviour. A current staff recruitment drive may alleviate problems, although it may take time for this to take effect and for staff to develop the necessary experience' (IMB, 2014: 4).

The following summer, when I conducted my research, many uniformed officers reported that their time with detainees had declined and along with it, their pleasure, motivation and security in their work. Joseph spoke for many when he said, "I only spend 90 minutes a day talking to the guys. And they are the best part of my day" (DCM, IRC Colnbrook). Whereas criminological accounts of other custodial staff, usually emphasize the importance of staff-inmate relationships as a means of delivering legitimacy (Liebling, 2011; Crewe, 2011; Crewe et al, 2015), Joseph's testimony directs us to think about the affective implications of face-to-face encounters (Levinas, 1969; Hall, 2012). Communication and time spent with others are forms of recognition. While they may not necessarily always be positive, they are an important means by which we recognize and thereby sustain ourselves.

Without such mutual recognition, other, more negative emotions arise: fear, suspicion, and frustration. People often turn to alternative means to understand and relate to others. Thus, Joseph's colleague, Shaan, railed against the specifically, and unsubstantiated, gendered view of the risks she felt detainees posed in this institution where not only was she unable to know them, but also she felt alone and unsupported. Officers were often forced to work alone in housing units with over one hundred men, when their partner was called away to other matters. Management did not care, she complained: 'all it will take is one female officer getting assaulted on $C$ wing or $D$ wing during the night, the radio is not working, there's no cameras, something serious is gonna happen before anything will be done' (DCO, IRC Colnbrook). ${ }^{11}$

Just as the financial imperatives of the contracted-out model draw into question the role of custodial staff, so too, the bifurcation between the custodial provider and the Home Office challenges an easy account of their purpose and identity. Officially, DCOs are responsible for just one aspect of people's immigration case: their confinement. They have no role to play in the immigration matters that bring men and women to detention, and no powers to assist in resolving them either. Jane, explained:

11 On a return visit in July 2017, I walked around these two units, which together hold nearly 300 men, without seeing officers for hours at a time. The staff complement had been reduced to a pair of officers per unit, and, when I was there, they spent most of their time sequestered in their offices, behind opaque glass. 
My role as an officer here is really to keep the detainees safe and as happy as I can do until the Home Office make a decision on what's going to happen to them. But equally, my role is to support the Home Office in removing those that they then decide have to be removed. So, our role is completely split in two ways, really. (DCO, IRC Morton Hall).

And yet, the two systems are not entirely separate. DCOs may have no formal role in case-work decision-making, but they do pass information about detainees to the Home Office in regards to their overall 'compliance' with the regime and in security matters. The logic of this arrangement, for some was clear: 'if he's not compliant in a detention centre,' Hasan observed, 'then how likely will it be that he will comply with their [Home Office] demands in the community for reporting?' (DCM, IRC Harmondsworth). For others, however, the point of custodial work in a system oriented towards exclusion was hard to understand.

Four years into working as a detainee custody officer at IRC Morton Hall, having previously been employed for over a decade at the same institution as a prison officer, Jane still missed working with prisoners. The problems were manifold. Most fundamentally, she worried about the purpose of her work. 'With $a$ prisoner, she said:

'you can contribute with their parole report, things like that. Nothing like that. We're not allowed to fill in bail forms for them or anything. We're not allowed to complete any paperwork. Often, they'll ask... that you write a report for them to take to the court. We're not allowed to do that. The Home Office don't allow us to do that.' (DCO, IRC Morton Hall).

Under these circumstances, DCOs often feel as though they have little impact on the detainees' lives. Such uncertainty can be hard to bear, Jane made clear. 'We don't achieve anything. We don't educate anybody...' She could not consider herself an agent of change in this system, only of control. Even here, she felt impotent. Detainees were angry and she had few formal powers to control them. 'None of them, not one of them wants to be here in an immigration centre, obviously,' she said. 'But there aren't any sanctions. It's difficult to control their behavior because their anger is really directed at the Home Office, but they very rarely see the Home Office...'12

Unlike prisons, which are meant to prepare people for 'law abiding lives after release' and, therefore, are nominally at least, invested in and concerned about the effect of their confinement, IRCs are meant to facilitate removal and deportation but at the same time, do not engage with the consequences. Officers are forbidden from maintaining contact with detainees who leave and may be sacked for doing so. Once somebody departs, whether it is into the community,

\footnotetext{
12 While it is true that detainees have very limited contact with the Home Office caseworkers, who determine their fate, in some institutions the local Home Office team is more visible than it is at Morton Hall, where the onsite immigration officers who deliver information about people's immigration case, are located outside the fence of the institution (Bosworth and Slade, 2014).
} 
or to the airport, therefore, it is as though they were never present, no matter how much effort individual officers may have put into building a relationship with them. This rupture can be difficult to manage, in a moral sense (What happens to deportees? Are they safe?) but also in a more self-interested way, as the purpose of custodial work is trumped by a system whose overall purpose is singular: to expel. 'I try just to put them out of my head,' Joseph said weakly. 'I just put that out of my mind. For them, I think my job is to look after them while they're here and to keep them safe while they're here. And then what happens next, well, I don't think about.' (DCM, IRC Colnbrook)

Whereas the lack of engagement with the future is institutionally mandated, a more fundamental claim of ignorance about detainees and how they have ended up in the UK is common. IRCs appear to exist outside time and space. Expressed in racialized and gendered terms, staff like Peter, marvel at how so many different people 'end up in here, on some little island in Europe', conveniently overlooking Britain's imperial past and contemporary involvement in sites of global conflict and thereby dodging any sense of collective responsibility that might draw their work into question (DCM, IRC Colnbrook; cited in Bosworth, 2018). In more explicitly racially coded terms, Jane complained, 'It's quite difficult, everybody with their different cultures, different expectations.' The problem, she said eventually, was that 'a lot of the people from countries that we hold here, the detainees have absolutely no respect at all for females.' (DCO, IRC Morton Hall).

In articulating this widely-held, racialized and gendered view of foreign men, Jane does more than just make sense of the men she must look after, she effectively erases the powerlessness of the detainees and brings into being a relationship between (her) self and (their) other that was previously missing. Her embodied self, as a white woman, becomes the means by which she interprets those whom she otherwise cannot connect with or assist. For, as she goes on, meaningful relationships between staff and detainees in IRCs are prevented by the fact that, 'detainees don't believe that they've committed a crime, so feel as if they're being punished unnecessarily, really.' (DCO, IRC Morton Hall). In contrast to the prisoners she used to work with, whom, she insisted, had accepted their confinement as a legitimate consequence of their criminal actions, detainees are never reconciled to their incarceration. As a result, they can never accept her either.

The barriers and frustrations Jane lists were not just poor procedural practice. She was not, in other words, merely describing an institutional 'legitimacy deficit' of the kind more familiar to prisons scholarship (Sparks, 1994; Ugelvik, 2016). Rather, Jane describes her job as an assault on her own standing in the world. Most obviously, her agency and self-determination had been eroded. 'The actual interventions are not in your hands,' she complained. 'Everything is governed by the Home Office.' Her job, as a consequence, diminished herself.

'Mentally, it's very, very, very challenging. Because you don't make a difference to them, really. You make no difference. Whereas with a prisoner, you feel as though you're working towards something, you 
don't have that kind of satisfaction, really... We make no difference whatsoever.' (DCO, IRC Morton Hall)

Such matters, she made clear, were painful: 'I'm not saying we're worthless, but...' Elsewhere, in IRC Colnbrook, Gopal expressed a similar set of concerns. A young Asian man who had worked for a number of years at IRC Colnbrook, Gopal was wrestling with this aspect of his work when I interviewed him. 'This is not a happy environment, where you say, 'Good morning.' You know, you come in, and then you get on with your work, and then you're coming home,' he observed sadly. 'It's not a happy environment. Because they're, they're stressful [sic], they're locked up.' He felt tainted. 'You're locking people in before you go home,' he pointed out. 'So they're not... I mean, they know it's not your fault; you're just doing your job. But then it leaves a little mark in your head, you know. There's a negativity going on there.' (DCO IRC Colnbrook).

Officers frequently feel impugned by public critique, unappreciated by detainees and the wider community. 'The biggest struggle I have', Peter complained 'is when I read stories in the paper or on the web about how horrible we all are as staff, and we do this and we do that,' (DCM, IRC Harmondsworth). His colleague Joyce, who worked in the neighbouring institution of IRC Colnbrook, agreed. 'It can be quite demoralising sometimes,' she acknowledged,

'as you're the member of staff, and you know the good stuff that goes on, and how hard some of the staff really work, and how hard some of the residents work. And we all kind of get on. When you kind of see in the press it's only, like, you know, rats and, 'Oh, there's bedbugs, and there's no freedom, and there's this and there's that and... yeah, everything else.' So yeah, that can be a bit like... you just want to shout (...), you know, 'You can come in and see it for yourself. Spend a day. Don't just assume.' But then they're not allowed in, so...' (DCM, IRC Colnbrook).

Stan was less positive still and more terse. 'It is very hard work,' he said, 'and you can't leave it behind.' (DCO, IRC Yarl's Wood).

In all of these accounts, we catch a glimpse of shame and stigma, of frustration and disappointment. We are reminded, in Jack Katz' words, that emotions are a means by which people comment 'to themselves if not to others, on what the interaction that is occurring says about themselves in a given scene, and they also comment on the overall stories that they are constructing as they shape a path through life.' (Katz, 1999: 324). These are intense emotions that are hard to deflect or absorb. For Martha Nussbaum (2004: 199), shame is productive. It can, she writes, optimistically, be "morally valuable" and play "a constructive role in development and moral change." Yet, these officer testimonies are profoundly contradictory; it is unclear what path these staff members are shaping. In the immigration system, where his role was simply to hold people for the purpose of removal, Gopal did not want to feel 'marked' or stigmatized by his profession, yet he could see now alternative. Above all, staff want gratitude from those whom they coerce and control. They wish their commitment and expertise were 
recognized by the wider community who are never allowed into see their work. ${ }^{13}$ They want to connect in an environment based on exclusion.

Unable to resolve such contradictions, officers must instead try to manage their feelings. In the only other extant study of immigration detention staff, conducted by Alexandra Hall in 2001, just as the new generation of detention centres were starting to spring up, employees socialized with one another outside work, building their own 'community of understanding' (Hall, 2012). At Harmondsworth and Colnbrook in 2015, by contrast, officers said no such informal get togethers occurred. Like precarious workers everywhere, people commuted long distances, worked at multiple posts, and, in any case, wanted time away from thinking about their job.

Instead of a 'community of understanding', in interviews, officers described a series of barriers they created between their job and their life. Some relied on training they have received in previous kinds of jobs (often in the prison service or the police). Others depended on literal, geographical and temporal barriers. Whatever their strategy, they almost always described it just after they had made it quite clear that the job had affected their life, and thus that the strategy they were relying upon was unsuccessful.

For many, as might be expected, the gate was key. 'I have my life as two worlds', Matthew stated simply.

I have my World One, which is outside the gate with my wife, my kids and I try ... to think about them separately. So, when I'm off, off at home, I'm doing my father stuff and messing about. When I'm coming to work... by the time I get through all the gates and doors my mind-set is completely different. (DCM, IRC Heathrow).

His colleague Joyce took a similar approach but was rather less convinced it worked. 'I just kind of use the gate,' she said haltingly,

'I mean, ... there's no way you can switch off one hundred percent; no human can. If you say you can, you're absolutely lying. But... the gate is my key. Right, let's just forget about that - as much as you can. [But] If it's something major, you're never gonna be able to forget it.' (DCM, IRC Colnbrook).

Others connected spatial distance to a temporal one. 'I live twenty-five miles away from here, which gives me an hour to reflect, and either cheer up or calm down,' Peter reported (DCM, IRC Harmondsworth). It was difficult, he said, to draw the two sides of his life together. "I've got children," he said,

\footnotetext{
${ }^{13}$ Similar emotions were identified among Swedish civil servants in charge of processing immigration and refugee applications by Mark Graham (2002). As he writes: 'They felt that certain emotional responses were due them and that their own emotional responses to those of immigrant clients ought to signal to themselves a job well done; they should not be made to feel guilty by clients.' (221 - 222).
} 
"and they're screaming and running round. And your wife's yapping on. And you just want to tell everybody just to shut up... Because, especially as an officer who's on the wings, when all you've had all day is chat, chat, chat, chat, chat, chat, bang, bang, bang, slam, slam, slam - you want to kind of just go home and just have quiet." (DCM, IRC Harmondsworth).

Despite his attempts to separate his two lives, they often overlapped. "It's hard to switch off, coming from home in here," he remarked.

"I've snapped at guys in here before. I'm not proud of it. But the boiler's on the blink, it's the middle of winter, the kids are ill, you haven't slept, you've done thirteen hours the previous day, you've had about three hours sleep and you just snap..." (DCM, IRC Harmondsworth).

Joseph, who had worked for many years in the London Metropolitan Police Force, deployed a similar temporal and geographical tactic. "I live very close," he said, "about fifteen minutes drive from here. But there's a motorway between me and where I live; and I find that, when I drive, once I've crossed that motorway, I leave it all behind. There's my life on one side and there's work on the other." (DCM, IRC Colnbrook). Its effectiveness was limited however, he noted, when he reported rather helplessly, 'I don't have any good days. I just have sleepless nights' (DCM, IRC Colnbrook).

"You get hardened working in these places," Melvin noted simply. (DCO, IRC Harmondsworth). And as this happens, officers change. They not only feel different about themselves, but their views of those they are looking after shift as well. Officers become more cynical, less emotionally available or open. As Imran put it, "To start with, seeing self-harm affected me, yes. I was a bit shocked, but now, I've got to say, no. Once I've dealt with it I move on. I have to, you know. Because I don't know what's going to happen next and I have to be ready." (IRC Harmondsworth, DCM).

\section{Conclusion}

Authority, according to Richard Sennett, is 'a bond between people who are unequal' (1980: 10). While liberal scholars since have spent considerable effort excavating the 'bond' that exists between those in an unbalanced relationship, the testimonies from staff in this article suggest a somewhat darker reality, in which people are sundered not only from one another but from themselves. IRCs, designed as places to contain and then cast out those who are unwelcome, not only split the community in which they are based, but those who work within them.

Rendered precarious by the contracted-out system and destabilised by the lack of clarity over the purpose of their job, officers find it hard to maintain an integrated sense of self. Instead, they must set aside their 'authentic' self, leaving it outside the gate. Within the gate, they are someone else. 
This task is impossible to maintain. Everyone sometimes is confronted by another self they recognise (Bosworth, 2016), even if it is only their own (Arendt, 2003). As Alexandra Hall observes, the logic of exclusion, within detention, is punctuated by 'ethical encounters' (Hall, 2012; Levinas, 1969). Thus, while much of her book is concerned with the mechanisms through which officers 'reduce' detainees 'to a series of biological processes' or transform them 'into objects to be processed,' Hall notes that 'the discretionary power that officers held.... Always contained the potential for a response to the detainee that recognized him as more than a 'detainee'.' (Hall, 2012: 19).

On the one hand, she writes, detainees, and staff, become subject to a disciplinary regime that aims to fix, arrange and train individuals in time and space to achieve an ordered, secure establishment.' (Hall, 2012: 11). On the other hand, she suggests, 'if the everyday life of detention is where power and control penetrates individual bodies and the textures of social life, it is also where power and resistance play out agonistically.' (Hall, 2012: 11). Invoking the work of Emmanuel Levinas (1969), she describes how 'ethical moments', or 'ethical encounters', when staff and detainees recognize one another and talk, exist 'in stark contrast to the antagonistic and divisive social relations' that usually occur between detainees and staff (Hall, 2012: 20). They dissolve and transcend the boundaries created by the institution, however briefly, can be considered 'cosmopolitan' instances, 'grounded in shared capacities such as empathy and embodied vulnerability' (Hall, 2012: 20).

While Levinas (1969) emphasises our relationship and interactions with the Other as a means of understanding ourselves, and thus our capacity for acting ethically and morally, IRCs structurally, practically and symbolically limit such encounters. Whether it is the 'hotel model' that reduces staff numbers and champions a customer service model in which matters of dignity or compassion have little role to play, or the Home Office's 'hostile environment' that casts foreigners as inherently untrustworthy and undesirable, it is hard to find the building blocks of recognition.

In this final point, we see how profoundly IRCs undermine the key tenets of liberal political philosophy, 'the equal worth of persons and their liberty' (Nussbaum, 2004: 66). In negating the other and the self, immigration detention constructs a different form of power and authority, in which arguments over legitimacy have no currency. The consequences: high levels of detainee distress, and suicide, alongside rapid staff turnover and institutional violence are endemic across the system.

In June 2018, in the audio recordings of crying children who had been forcibly separated from their mothers at the US-Mexico border and the custodial staff dismissing them, we witnessed what can happen when authority works without recognition. For as Arendt and Levinas warned so long ago, in a system and a society that is not based on recognition of the Other or the Self, the foundations of moral responsibility may crumble. Under such circumstances, it is unclear what the limits might be on the power of the state, nor how we might call it to 
account. Put another way, what precisely are we prepared to do to ensure that foreigners leave? 


\section{References}

Aas, K.F. and Bosworth, M. (eds). The Borders of Punishment. Oxford: Oxford University Press.

Ahmed, S. (2004a). The Cultural Politics of Emotions. London: Routledge.

Ahmed, S. (2004b). 'Affective Economies', Social Text 79 Volume 22(2): 117 139.

Arendt, H. (2003). Responsibility and Judgment. New York: Schocken Books.

Bosworth, M. (2018). "Working in this place turns you racist": Staff, Race and Belonging in Immigration Detention', in M. Bosworth, A. Parmar and Y. Vázquez. (Eds). Race, Migration and Criminal Justice: Enforcing the Boundaries of Belonging. Oxford: Oxford University Press. pp. 214 - 228.

Bosworth, M. (2018). 'Annex 10. Staff culture in immigration removal centres.' In Assessment of Government Progress in Implementing the Report on the Welfare in Detention of Vulnerable Persons: A Follow-Up Report to the Home Office by Stephen Shaw. Cm 9661. London: HMSO. pp. 207 - 211.

Bosworth, M. (2016). 'Immigration Detention, Ambivalence and the Colonial Other,' In A. Eriksson (Ed.). Punishing the Other. Abingdon: Routledge, pp. 145 $-164$.

Bosworth, M. (2014). Inside Immigration Detention. Oxford: Oxford University Press.

Bosworth, M. (2013). 'Can Immigration Detention be Legitimate?', in K.F. Aas and M. Bosworth. (Eds.). Migration and Punishment: Citizenship, Crime Control, and Social Exclusion. Oxford: Oxford University Press. pp. 149 - 164.

Bosworth, M., Gerlach, A. and D. Aitken. (2016). Understanding Staff Culture at IRC Heathrow. Oxford: Centre for Criminology.

Bosworth, M., and Kellezi, B. (2017). 'Doing research in immigration removal centres: ethics, emotions and impact.' Criminology \& Criminal Justice. 17(2): 121-137.

Bosworth, M. and Slade, G. (2014). 'In Search of Recognition: Gender and StaffDetainee Relations in a British Immigration Detention Centre.' Punishment \& Society. 16(2): 169 - 186.

Bottoms, A.E. and Tankebe, J. (2012). 'Beyond procedural justice: A dialogic approach to legitimacy in Criminal Justice.' The Journal of Criminal Law \& Criminology. 102(1): 119 - 170. 
Bradford, B., and Quinton, P. (2014). 'Self-Legitimacy, Police Culture and Support for Democratic Policing in an English Constabulary,' British Journal of Criminology. 54: 1023 - 1046.

Braithwaite, J. (1989), Crime, Shame and Reintegration. Cambridge: Cambridge University Press.

Brown, M. and Schept, J. (2017). 'New Abolition, Criminology and a Critical Carceral Studies,' Punishment \& Society. 19(4): 440 - 462.

Cohen, S. and Taylor, L. (1979). Psychological Survival: The Experience of LongTerm Imprisonment. Harmondsworth: Penguin.

Chamberlen, A. (2016). 'Embodying Prison Pain: Women's' self-injury practices in prison and the emotions of punishment', Theoretical Criminology. 20(2): $205-219$.

Clough, P., and Halley, J. (2007). The Affective Turn: Theorizing the Social. Duke University Press.

Crawley, E. (2014). 'Managing Prisoners, Managing Emotion: The Dynamics of Age, Culture and Identity', in Karstedt, S., Loader, I., and Strang, H. (Eds.). (2011). Emotions, Crime and Justice. Oxford: Oxford University Press. pp. 255 $-271$.

Crawley, E. (2004a). Doing Prison Work: The Public and Private Lives of Prison Officers. Cullompton: Willan.

Crawley, E. (2004b). 'Emotion and performance: Prison Officers and the Presentation of Self in Prisons,' Punishment \& Society. 6(4): 411 - 427.

Crewe, B. (2011). 'Soft power in prison: Implications for staff-prisoner relationships, liberty and legitimacy,' European Journal of Criminology, 8(6): $455-468$.

Crewe, B. (2009). The Prisoner Community. Oxford: Oxford University Press.

Crewe, B, Liebling, A. and S. Hulley (2015). 'Staff-Prisoner Relationships, Staff Professionalism and the use of Authority in Public- and Private-Sector Prisons', Law \& Social Inquiry. 40(2): 309 - 344.

Dolovich, S. (2004). 'Legitimate Punishment in Liberal Democracy,' Buffalo Criminal Law Review 7(2): 307-442.

Graham, M. (2002). 'Emotional Bureaucracies, Emotions, Civil Servance and Immigrants in the Swedish Welfare State,' Ethos, 30(3): 199 - 226. 
Hall, A. (2010). 'These People Could Be Anyone': Fear, Contempt (and Empathy) in a British Immigration Removal Centre,' Journal of Ethnic and Migration Studies, 36(6): $881-898$.

Hall, A. (2012). Border Watch: Cultures of Immigration, Detention and Control. London: Pluto Press.

Haney, L. (2016). 'Prisons of the past: Penal nationalism and the politics of punishment in Central Europe,' Punishment \& Society, 18(3): 346 - 368.

HMIP. (2018). Report of an unannounced Inspection of Heathrow Immigration Removal Centre Harmondsworth Site. London: HMIP.

Home Office (2018). Immigration Statistics, year ending March 2018. Available at: https://www.gov.uk/government/statistics/immigration-statistics-yearending-march-2018. Accessed 6 July 2018.

Honig, B. (2001). Democracy and the Foreigner. Princeton, NJ: Princeton University Press.

Karstedt, S., Loader, I., and Strang, H. (Eds.). (2011). Emotions, Crime and Justice. Oxford: Oxford University Press.

Katz, J. (1999). On Emotions. Chicago: University of Chicago Press.

Katz, J. (1988). Seductions of Crime: Moral and Sensual Attractions in Doing Evil. Berkeley, CA: California University Press.

IMB (2014). Harmondsworth Immigration Removal Centre, Annual Report 2014. London: IMB. Available at: http://www.imb.org.uk/wpcontent/uploads/2015/04/Harmondsworth-IMB-Annual-Report-2014.pdf. Last accessed 19 June 2017.

Lerman, A. and Page, J. (2012). 'The State of the Job: An Embedded Work Role Perspective on Prison Officer Attitudes,' Punishment \& Society. 14(5): 503 529.

Levinas, E. (1969). Totality and Infinity: An Essay on Exteriority. Duquesne University Press.

Liebling, A. (2011). 'Distinctions and distinctiveness in the work of prison officers: Legitimacy and authority revisited', European Journal of Criminology, 8(6): $484-499$.

Liebling, A. (2004). Prisons and their Moral Performance. Oxford: Oxford University Press.

Liebling, A. and J. Tankebe. (Eds). (2015). Legitimacy and Criminal Justice: An International Exploration. Oxford: Oxford University Press. 
Mercan, B. (2018). 'Doing Criminological Research: Affective States Versus Emotional Reactions', Theoretical Criminology. Online First. http://journals.sagepub.com/doi/full/10.1177/1362480618779399

Murphy, K., \& Tyler, T. (2008). 'Procedural justice and compliance behaviour: the mediating role of emotions', European Journal of Social Psychology, 38: 652668.

Nussbaum, M. (2004). Hiding from Humanity: Disgust, Shame, and the Law. Princeton: Princeton University Press.

Nussbaum, M. (2001). Upheavals of Thought: The Intelligence of Emotions. Cambridge: Cambridge University Press.

Sedgwick, E. K. (2003). Touching Feeling: Affect, Pedagogy, Performativity, Durham, NC: Duke University Press.

Sennett, R. (1980). Authority. New York: Alfred A. Knopf publishing.

Shaw, S. (2018). Assessment of Government Progress in Implementing the Report on the Welfare in Detention of Vulnerable Persons: A Follow-Up Report to the Home Office by Stephen Shaw. Cm 9661. London: HMSO.

Sparks, R. (1994). 'Can Prisons be Legitimate? Penal Politics, Privatization and the Timeliness of an Old Idea', British Journal of Criminology. 34: 14 - 28.

Sparks, R., Bottoms, A.E. and Hay, W. (1996). Prisons and the Problem of Order. Oxford: Oxford University Press.

Sykes, G. (1958). The Society of Captives: A Study of a Maximum Security Prison. Princeton: Princeton University Press.

Ugelvik, T. (2016). 'Techniques of legitimation: The narrative construction of legitimacy among immigration detention officers', Crime, Media Culture. 12(2): $215-232$.

Weber, M. (1997). The Protestant Ethic and the Spirit of Capitalism. London: Routledge.

Wooldredge, J., and Steiner, B. (2016). 'The Exercise of Power in Prison Organizations and Implications for Legitimacy', The Journal of Criminal Law \& Criminology. 106(1): 125 - 166. 